\title{
Determination of Umbralisib using reverse phase ultra performance liquid chromatography in bulk and pharmaceutical dosage form
}

\author{
Ramadevi Potturi*, Rambabu Kantipudi \\ Department of Chemistry, RVR \& JC College of Engineering, Chowdavaram, Guntur, AP, India.
}

\begin{tabular}{|c|c|}
\hline ARTICLE INFO & ABSTRACT \\
\hline Received on: & Main goal of this research is to develop and validate a simple, specific, precise, and sensitive Reverse phase Ultra \\
\hline Accepted on: 22/10/2021 & Performance Liquid Chromatography (RP-UPLC) method for the quantitative determination of Umbralisib in bulk \\
\hline Available Online: 05/02/2022 & $\begin{array}{l}\text { and pharmaceutical dosage form that is also cost effective and rapid. A UV detector with a detection wavelength of } \\
219 \mathrm{~nm} \text { was used to observe the wavelength of the analyte during its elution on Kinetex column of dimensions } 100 \times\end{array}$ \\
\hline $\begin{array}{l}\text { Key words: } \\
\text { RP-UPLC, Umbralisib, } \\
\text { development, validation. }\end{array}$ & $\begin{array}{l}4.6 \mathrm{~mm}, 2.6 \mu \mathrm{m} \text { with a moving phase composed of } 0.1 \% \text { formic acid: acetonitrile }(40: 60 \mathrm{v} / \mathrm{v}) \text { delivered at a stream of } \\
1.0 \mathrm{ml} / \mathrm{minute} \text {. The linearity of this method was demonstrated for Umbralisib over a concentration range of } 2-30 \mu \mathrm{g} / \\
\mathrm{ml} \text {, with a correlation coefficient of } 0.999 \text {. Using a } 3 \text {-minute run time, it was discovered that Umbralisib retention time } \\
\text { was } 1.554 \text { minutes. The results of the validation were in excellent agreement with the acceptable limits. Statistically } \\
\text { significant differences Relative standard deviation (RSD) of less than } 2.0 \% \text { indicate that this method is accurate and } \\
\text { precise. The proposed method was, therefore, deemed to be suitable for the regular analysis and quality control of } \\
\text { pharmaceutical preparations containing active drug, as demonstrated by the results of the experiment. }\end{array}$ \\
\hline
\end{tabular}

\section{INTRODUCTION}

Ukoniq, also known as Umbralisib, is a drug (da Fonseca et al., 2017) used to combat marginal zone lymphoma (MZL) (Bron and Meuleman, 2019; Sriskandarajah and Dearden, 2017) and follicular lymphoma (FL) (Boughan and Caimi, 2019; Takata et al., 2018). The patient ingests it. The most frequently observed side effects are an increase in creatinine (McDonald et al., 2012; Samra and Abcar, 2012), diarrhea, colitis (Sun et al., 2015; Yang et al., 2015), fatigue (Marcora et al., 2009), nausea (Scorza et al., 2007), neutropenia (Donadieu et al., 2017; Hsieh et al., 2007), transaminase elevation (Giboney, 2005; Oh and Hustead, 2011), musculoskeletal pain (Kumaraveloo and Lunner Kolstrup, 2018; Mishra and Sarkar, 2021), anemia, thrombocytopenia (Ahmed et al., 2007), upper respiratory tract infection (Grande et al., 2015), vomiting, abdominal pain (Tytgat, 2007; Viniol et al., 2014), a rash and a decreased appetite Umbralisib is a class of kinase inhibitor that includes PI3K-delta (Sarker et al., 2015)

*Corresponding Author

Ramadevi Potturi, Department of Chemistry, RVR JC College of

Engineering, Guntur, India. E-mail: ramadeviresearchanu@gmail.com and casein kinase CK1-epsilon. The phosphoinositide-3-kinases (PI3Ks) are a family of enzymes involved in many important cellular functions, including cell proliferation and survival, cell differentiation, intracellular trafficking, and immunity. There are four isoforms of PI3K (alpha, beta, delta, and gamma), of which the delta isoform is highly expressed in hematopoietic cells and malignant lymphoid diseases. Dysregulation of the PI3K pathway is among one of the most commonly mutated pathways across all of cancer biology. Umbralisib is highly selective for the delta isoform of PI3K and has limited to no impact on the other PI3K iso forms. CK1-epsilon (Burris et al., 2018; Lunning et al., 2019) is a major regulator of oncoprotein translation, which drives growth and survival of lymphoma cells, including c-Myc. For adults with MZL recurrence or refractory MZL who have received at least one prior anti-CD20 (Kuijpers et al., 2010) based regimen, and adults with relapsed or refractory FL who have received at least three prior lines of systemic therapy, Umbralisib is indicated. The drug's prescribing information also alerts patients to the adverse reactions they should watch out for, including infections, neutropenia, diarrhoea, and non-infectious colitis, as well as hepatotoxicity (Mumoli et al., 2006; Riordan and Williams, 2002), and severe cutaneous reactions (Mumoli et al., 2006; Riordan and Williams, 


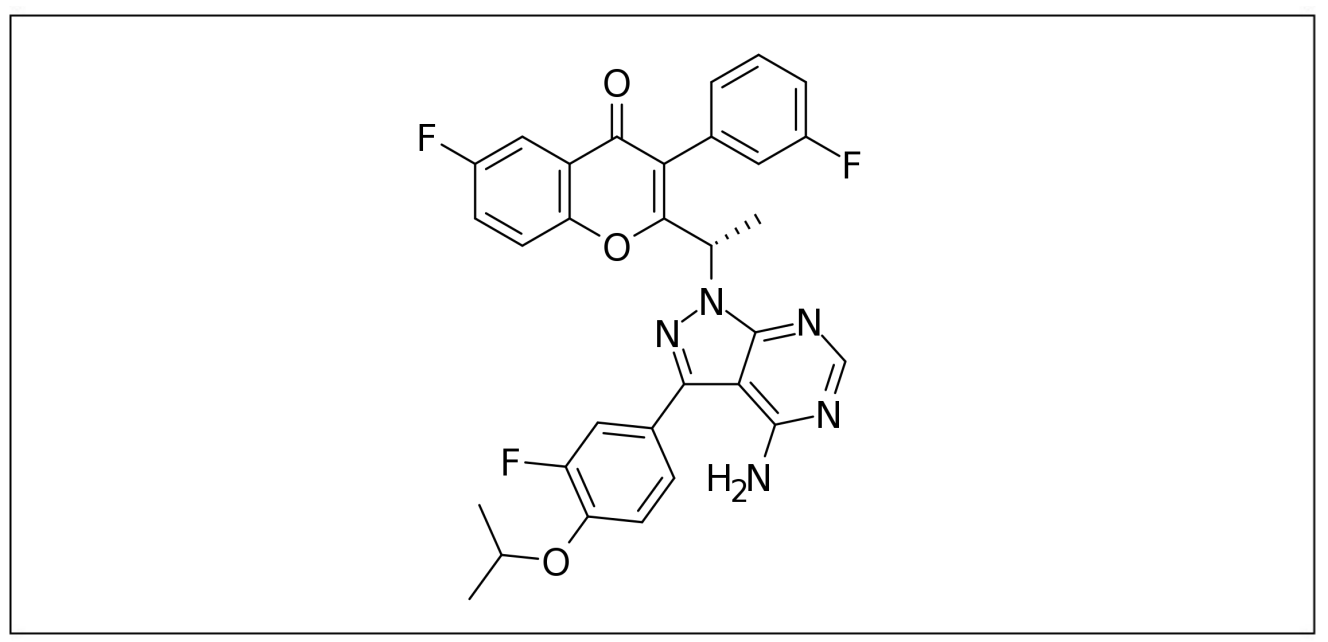

Figure 1. Chemical structure of Umbralisib.

2002). Its effects on chronic lymphocytic leukemia (Gribben, 2009; Kipps et al., 2017) have been tested in clinical trials. Mantle cell lymphoma (Rajabi and Sweetenham, 2015; Skarbnik and Goy, 2015) is just one of many cancers they are testing in combination trials and other lymphomas. For the MZL indication, priority review was given to the application for Umbralisib, and it was also designated as an orphan drug for the treatment of MZL and FL. Figure 1 represents the chemical representation of Umbralisib.

UPLC was used to quantify Umbralisib in the present research. Until now, there were no quantification methods for Umbralisib. Developing an UPLC strategy for the creation of Umbralisib has gained more interest than developing other strategies. UPLC offers better separation and can thus yield more information in a short period of time than High Performance Liquid Chromatography (HPLC). Thus, UPLC separation techniques were employed for the purpose of separating Umbralisib.

\section{EXPERIMENTAL STUDY}

\section{Solutions and reagents}

This research was supported by Glenmark Pharmaceutical Private Ltd., Andheri (E), Mumbai, India, which provided the pure Umbralisib standard and samples used in this research $(99.7 \%$ 99.9\% purity). Everything else, including acetonitrile, triethyl amine, and water, was obtained from Merck (India) Ltd. Worli in Mumbai and was of $99.99 \%$ purity for UPLC analysis.

\section{Equipment}

The researchers used a Waters Acquity chromatographic device equipped with a quaternary pump, variable UV, and Photo Diode Array (PDA) detectors to conduct the experiment. When it came to data collection and processing, we turned to the chromatographic programme Empower-2.0.

\section{Step of mobility}

In this study, the mobile step consisted of $0.1 \%$ formic acid buffer in a 40:60 (v/v) acetonitrile mixture that was degassed prior to review. The selected mobile phase produced a sharp peak with a low tailing factor (2.0), as well as a plate count of more than 2,000, which was satisfactory.
Diluent

Mobile phase was used as diluents.

\section{Conditions of chromatography}

Kinetex column $(100 \times 4.6 \mathrm{~mm}, 2.6 \mu \mathrm{m})$ was used in the UPLC experiments. In this example, the process is isocratic elution with acetonitrile, which delivers formic acid (0.1\%) (60:40 $\mathrm{v} / \mathrm{v}$ ) as a mobile step at a stream of $1.0 \mathrm{ml} /$ minute. To calculate the amount of the injection required, $10 \mu \mathrm{l}$ of solution was injected into the injection channel and the experiment ran for 3 minutes, with the machine temperature kept at ambient. The sample was then taken out of the instrument and the absorbance was measured at $219 \mathrm{~nm}$ (because it gives the maximum absorbance of the Umbralisib). The proposed method was validated according to International Conference on Harmonisation (ICH) guidelines.

\section{Standard solution preparation}

Measure and carefully weigh out $20 \mathrm{mg}$ of Umbralisib into a volumetric flask with a capacity of $100 \mathrm{ml}$, then mix in an additional $70 \mathrm{ml}$ of diluents. Sonicate the solution for 30 minutes to thoroughly dissolve it. Finally, top off the flask with additional diluents. To dilute the solution, add $5 \mathrm{ml}$ of the other solution to 50 $\mathrm{ml}$ of the original solution.

\section{Preparation of the sample}

Consider the measurements, and weigh out $27.8 \mathrm{mg}$ of the powder from each tablet of the tablet form of Umbralisib (200 mg of the drug). Transfer that weight to a flask with a capacity of $100 \mathrm{ml}$, along with $70 \mathrm{ml}$ of diluent. To achieve the desired consistency, it is sonicated first and then diluted. Add 50 $\mathrm{ml}$ of water to the solution and then filter it using a 0.45 -micron syringe filter.

\section{RESULTS AND DISCUSSION}

The study's goal is to develop a single isocratic UPLC method for the quantitative determination of Umbralisib in bulk and pharmaceutical dosage form that is accurate, precise, and economical. Developers tested acidic buffers, methanol, and acetonitrile with isocratic development procedures. Various stationary phases were 
Table 1. Method suitability conditions.

\begin{tabular}{cc}
\hline Parameter & Suitable conditions \\
\hline Column & Kinetex column $(100 \times 4.6 \mathrm{~mm}, 2.6 \mu)$ \\
Moving phase & $0.1 \%$ formic acid:acetonitrile $(40: 60 \mathrm{v} / \mathrm{v})$ \\
Volume of injection & $10 \mu 1$ \\
Stream rate & $1.0 \mathrm{ml} / \mathrm{minute}$ \\
Temperature of column & Ambient \\
Wave length & $219 \mathrm{~nm}$ \\
Time duration & 3 minutes \\
Retention time of Umbralisib & 1.554 minutes \\
\hline
\end{tabular}

Table 2. Results of system suitability.

\begin{tabular}{cc}
\hline Parameter & Umbralisib \\
\hline Number of plates & 3,524 \\
Tailing & 1.07 \\
Resolution & - \\
Peak elution time & 1.554 \\
\hline
\end{tabular}

used, including phenyl, biphenyl, amino, $\mathrm{C} 4$, and $\mathrm{C} 8$. Also, the mobile step plate count and retention time was changed at each trial to improve results. Kinetex column $(100 \times 4.6 \mathrm{~mm}, 2.6 \mu \mathrm{m})$ and a moving phase of $0.1 \%$ formic acid:acetonitrile $(60: 40 \mathrm{v} / \mathrm{v})$ with a UV detector set to monitor at $219 \mathrm{~nm}$ were utilised. For the entire run of the show, it lasted 3 minutes. Chromatographic conditions optimized in Table 1 are shown.

\section{System suitability}

After six injections of a normal solution, device suitability parameters, such as theoretical plate number, time, peak area, tailing factor, and resolution, were collected from Empower software. Table 2 contains the system suitability results, while Figure 2 shows the chromatogram produced using the standard method.

\section{Specificity}

None of Umbralisib was found in the eluent during the time it was in contact with blank and placebo. This is shown in Figure 3 .

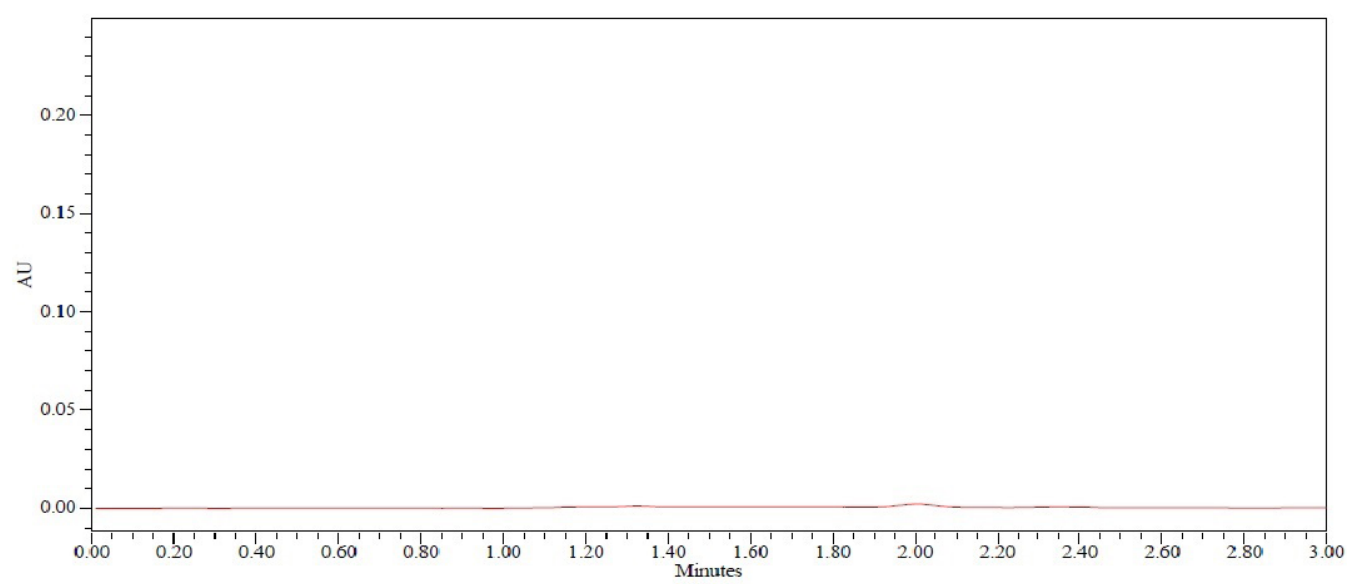

Figure 2. Chromatogram of blank.

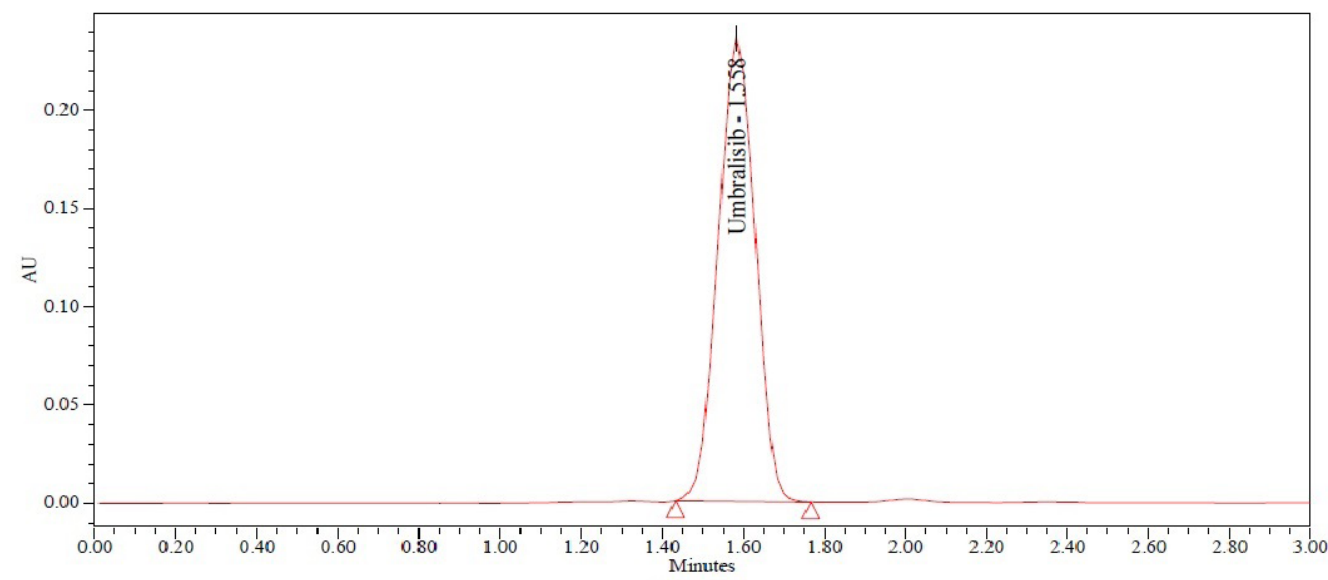

Figure 3. Chromatogram of standard. 
Table 3. Results of linearity.

\begin{tabular}{ccc}
\hline \multirow{2}{*}{ S. No } & \multicolumn{2}{c}{ Umbralisib } \\
\cline { 2 - 3 } & Concentration $(\boldsymbol{\mu g} / \mathbf{m l})$ & Area \\
\hline 1 & 2.00 & 304,880 \\
2 & 5.00 & 729,113 \\
3 & 10.00 & $1,436,209$ \\
4 & 15.00 & $2,106,347$ \\
5 & 20.00 & $2,934,505$ \\
6 & 25.00 & $3,558,517$ \\
7 & 30.00 & $43,55,617$ \\
CC & & 0.99974 \\
Slope & & $144,151.28$ \\
Intercept & & 125.15 \\
\hline
\end{tabular}

\section{Linearity}

Linearity was discovered by drawing a calibration curve of the area of peak concentration against its corresponding concentration $(10 \%, 25 \%, 50 \%, 75 \%, 100 \%, 125 \%$, and $150 \%)$. It was possible to deduce from this calibration curve that the graph represented a straight line within the range of 2 to $30.0 \mu \mathrm{g} / \mathrm{ml}$ of Umbralisib. $Y$ is calculated as $144,151 X+125\left(R^{2}-0.9997\right)$. In the study, the results were shown in Table 3, and in Figure 4, the calibration plot of Umbralisib was shown. From the linearity calculation sheet, the slope, intercept, and correlation coefficient values were found.

\section{Precision}

This procedure was studied to evaluate both intraday and intermediate intraday precision. Analyzing the sample solution of Umbralisib six times on the same day with the same conditions enabled the intraday studies to be done. This system was examined in the same laboratory by evaluating the data using
Table 4. Outcomes of method precision.

\begin{tabular}{cc}
\hline S. No. & Area of Umbralisib \\
\hline 1 & $2,985,474$ \\
2 & $2,993,652$ \\
3 & $2,974,581$ \\
4 & $2,965,348$ \\
5 & $2,958,614$ \\
6 & $2,993,602$ \\
Mean & $2,978,545$ \\
Std. dev & $14,765.26$ \\
\% RSD & 0.496 \\
\hline
\end{tabular}

various instruments and examiners to investigate the accuracy. It is exceptionally precise, with Relative standard deviation (RSD) percentage values of less than $2 \%$. Meaningful recovery of usable drug occurred each time the process was conducted at a higher concentration, implying that the procedure was accurate. The Table 4 demonstrates the quality of the method precision results and the Figure 5 shows the method precision chromatogram.

\section{Intermediate precision (ruggedness)}

Intermediate precision results were shown in Table 5.

\section{Accuracy}

The precision was achieved through the three-stage measurement of the recovery experiments $(50 \%, 100 \%$, and $150 \%$ ). Umbralisib levels of 10,20 and $30 \mu \mathrm{g} / \mathrm{ml}$ were used in Active Pharmaceutical Ingredient (APIs). Triple injection of the test solution for each spike was performed and the test process was performed. The recovery rate was $100 \%$ similar, while the RSD rate was below $2 \%$. The percentage of recovered data was determined, together with the average and relative standard

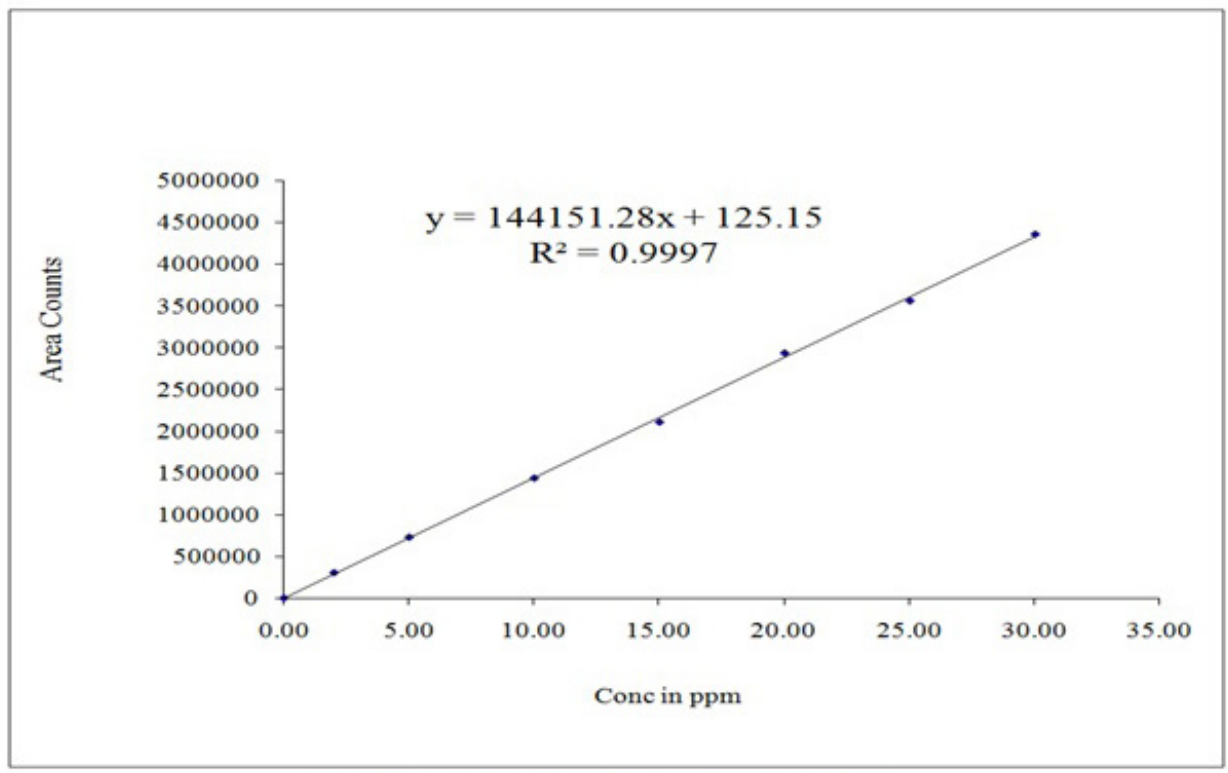

Figure 4. Calibration plot of Umbralisib. 


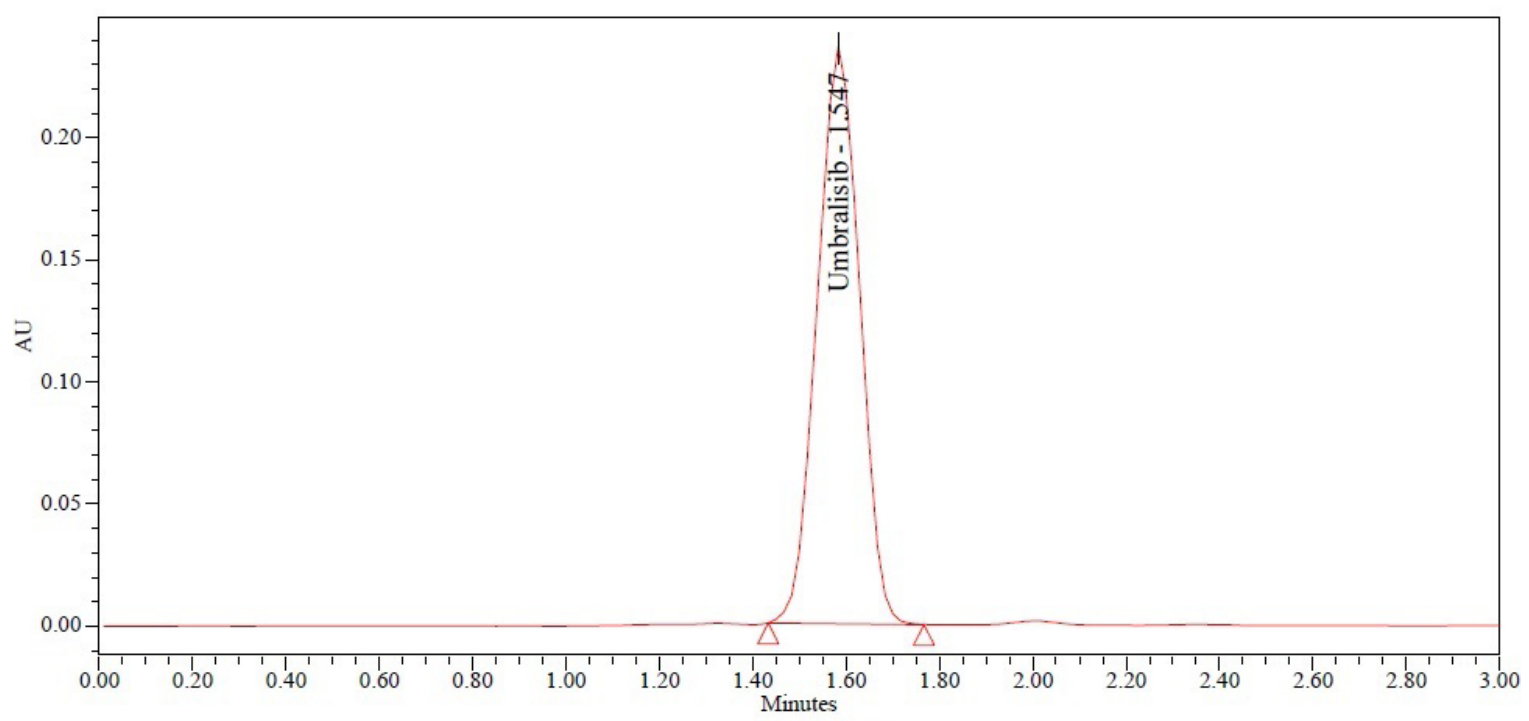

Figure 5. Sample chromatogram.

Table 5. Results of intermediate precision.

\begin{tabular}{ccc}
\hline S.No. & Area of Umbralisib & RSD \\
\hline 1 & $2,956,418$ & \\
2 & $2,941,785$ & \\
3 & $2,963,285$ & 1.84 \\
4 & $2,915,784$ & \\
5 & $2,936,547$ & \\
6 & $2,817,548$ & \\
\hline
\end{tabular}

Table 6. Results of accuracy.

\begin{tabular}{ccc}
\hline Accuracy & Amount of Umbralisib & \% Recovery \\
\hline $50^{\mathrm{a}}$ & 50 & 100.5 \\
$100^{\mathrm{a}}$ & 100 & 100.3 \\
$150^{\mathrm{a}}$ & 150 & 99.1 \\
\hline
\end{tabular}

${ }^{\text {a }}$ Results are mean recovery of three sample preparations.

Table 7. Outcomes of robustness.

\begin{tabular}{cc}
\hline Parameter & \% RSD of Umbralisib \\
\hline Flow $(0.8 \mathrm{ml} /$ minute $)$ & 0.42 \\
Flow $(1.2 \mathrm{ml} /$ minute $)$ & 0.65 \\
Organic phase $(54: 46)$ & 0.37 \\
Organic phase $(66: 34)$ & 0.82 \\
\hline
\end{tabular}

variations. The approach was successful because the recuperation values were within the scope. Table 6 shows accuracy results.

\section{Robustness}

In the evaluation of chromatographic technique, the fluctuations in flow rate and the movement composition of phases were used. The RSD percentage was determined to be within reasonable limits. Table 7 shows robustness results.

\section{Forced degradation}

The proposed approach can be used for successful release and stability test evaluations and can be called a preferable stability technology. The required forced degradation analysis includes acid, alkali, oxidation, reduction, hydrolysis, and thermal degradation. The chromatograms show that, despite the presence of degraded peaks, the selected drugs remained stable under pressure conditions. The purity of the peak can be detected by using PDA detector. Table 8 shows the results of forced degradation.

\section{Acid degradation}

$1 \mathrm{ml}$ of sample stock solution was moved to a volumetric flask of $10 \mathrm{ml}$, add $1 \mathrm{ml}$ of $1 \mathrm{~N} \mathrm{HCl}$ and left it for 15 minutes. After 15 minutes, add $1 \mathrm{ml}$ of $1 \mathrm{~N} \mathrm{NaOH}$ and make up to the diluent mark. Filter the solution using syringe filter and injected into UPLC system.

\section{Alkali degradation}

$1 \mathrm{ml}$ of sample stock solution was moved to a volumetric flask of $10 \mathrm{ml}$, add $1 \mathrm{ml}$ of $1 \mathrm{~N} \mathrm{NaOH}$ and left it for 15 minutes. After 15 minutes, add $1 \mathrm{ml}$ of $1 \mathrm{~N} \mathrm{HCl}$ and make up to the mark. Filter the solution using syringe filter and injected into UPLC system.

Table 8. Outcomes of FD.

\begin{tabular}{cc}
\hline Stress parameter & $\begin{array}{c}\text { \% Degradation of } \\
\text { Umbralisib }\end{array}$ \\
\hline Acid degradation $(1 \mathrm{~N} \mathrm{HCl})$ & 13.1 \\
Alkali degradation $(1 \mathrm{~N} \mathrm{NaOH})$ & 13.6 \\
Peroxide degradation $(30 \%$ peroxide $)$ & 12.4 \\
Reduction degradation $(30 \%$ sodium bi sulphate $)$ & 14.2 \\
Thermal (sample, $70^{\circ} \mathrm{C}, 6$ hours $)$ & 11.6 \\
Hydrolysis $(1 \mathrm{ml}$ of water $)$ & 10.9 \\
\hline
\end{tabular}




\section{Peroxide degradation}

$1 \mathrm{ml}$ of sample stock solution was moved to a volumetric flask of $10 \mathrm{ml}$, add $1 \mathrm{ml}$ of $30 \%$ hydrogen peroxide solution and make up to the mark with diluents. Filter the solution using syringe filter and injected into UPLC system.

\section{Reduction degradation}

$1 \mathrm{ml}$ of sample stock solution was moved to a volumetric flask of $10 \mathrm{ml}$ and add $1 \mathrm{ml}$ of $30 \%$ sodium bi sulphate solution and make up to the mark with diluents. Filter the solution using syringe filter and injected into UPLC system.

\section{Thermal degradation}

The sample solution was set in an oven at $105^{\circ} \mathrm{C}$ for 6 hours. The resultant solution was injected into UPLC system.

\section{Reduction degradation}

$1 \mathrm{ml}$ of sample stock solution was moved to a volumetric flask of $10 \mathrm{ml}$ and add $1 \mathrm{ml}$ of UPLC grade water and make up to the mark with diluents. Filter the solution using syringe filter and injected into UPLC system.

\section{CONCLUSION}

A novel, fast, low-cost, sensitive, and easy-to-access UPLC method was developed in this study to estimate Umbralisib in API and pharmaceutical dosage. The major advantage of this approach is that there are no UPLC methods. Low-cost, easier to use, more sensitive, reliable, and reproducible operations are all benefits. The analysis of many samples requires these characteristics to be critical. All parameters, including linearity, accuracy, specificity, robustness, and precision of process, were validated and found to be within reasonable limits. The RSD values for the parameters were $<2 \%$, indicating an accurate procedure and a reasonably consistent result obtained from that method. In the Quality Control (QC) laboratories, the current method can therefore be used for routine study and Umbralisib pharmaceutical formulation.

\section{ACKNOWLEDGMENT}

Shree Icon Pharmaceutical Laboratories expresses their gratitude for the provision of all necessary facilities to successfully complete this research.

\section{AUTHOR CONTRIBUTIONS}

All authors made substantial contributions to conception and design, acquisition of data, or analysis and interpretation of data; took part in drafting the article or revising it critically for important intellectual content; agreed to submit to the current journal; gave final approval of the version to be published; and agree to be accountable for all aspects of the work. All the authors are eligible to be an author as per the international committee of medical journal editors (ICMJE) requirements/guidelines.

\section{FUNDING}

There is no funding to report.

\section{CONFLICTS OF INTEREST}

The authors report no financial or any other conflicts of interest in this work.

\section{ETHICAL APPROVALS}

This study does not involve experiments on animals or human subjects.

\section{DATA AVAILABILITY}

All data generated and analyzed are included within this research article.

\section{PUBLISHER'S NOTE}

This journal remains neutral with regard to jurisdictional claims in published institutional affiliation.

\section{REFERENCES}

Ahmed I, Majeed A, Powell R. Heparin induced thrombocytopenia: diagnosis and management update. Postgrad Med J, 2007; 83(983):575-82.

Boughan KM, Caimi PF. Follicular lymphoma: diagnostic and prognostic considerations in initial treatment approach. Curr Oncol Rep, 2019; 21(7):63.

Bron D, Meuleman N. Marginal zone lymphomas: second most common lymphomas in older patients. Curr Opin Oncol, 2019; 31(5):386-93.

Burris HA, Flinn IW, Patel MR, Patel MR, Fenske TS, Deng C, Brander DM, Gutierrez M, Essell JH, Kuhn JG, Miskin HP, Sportelli P. Umbralisib, a novel PI3K $\delta$ and casein kinase- $1 \varepsilon$ inhibitor, in relapsed or refractory chronic lymphocytic leukaemia and lymphoma: an open-label, phase 1, dose-escalation, first-in-human study. Lancet Oncol, 2018; 19(4):486-96.

Donadieu J, Beaupain B, Fenneteau O, Bellanné-Chantelot C. Congenital neutropenia in the era of genomics: classification, diagnosis, and natural history. Br J Haematol, 2017; 179(4):557-74.

da Fonseca EM, Shadlen KC. Promoting and regulating generic medicines: Brazil in comparative perspective. Rev Panam Salud Publica, 2017; 41(e5):2.

Giboney PT. Mildly elevated liver transaminase levels in the asymptomatic patient. Am Fam Physician, 2005; 71(6):1105-10.

Grande AJ, Keogh J, Silva V, Scott AM. Exercise versus no exercise for the occurrence, severity and duration of acute respiratory infections. Cochrane Database Syst Rev, 2015; (6):CD010596.

Gribben JG. Stem cell transplantation in chronic lymphocytic leukemia. Biol Blood Marrow Transplant, 2009; 15(1 Suppl):53-8.

Hsieh MM, Everhart JE, Byrd-Holt DD, Tisdale JF, Rodgers GP. Prevalence of neutropenia in the U.S. population: age, sex, smoking status, and ethnic differences. Ann Intern Med, 2007; 146(7):486-92.

Kipps TJ, Stevenson FK, Wu CJ, Croce CM, Packham G, Wierda WG, O’brien S, Gribben J, Rai K. Chronic lymphocytic leukaemia. Nat Rev Dis Prim, 2017; 3:16096.

Kuijpers TW, Bende RJ, Baars PA, Grummels A, Derks IA, Dolman KM, Beaumont T, Tedder TF, van Noesel CJ, Eldering E, van Lier RA. CD20 deficiency in humans results in impaired T cell-independent antibody responses (PDF). J Clin Invest, 2010; 120(1):214-22.

Kumaraveloo KS, Lunner Kolstrup C. Agriculture and musculoskeletal disorders in low- and middle-income countries. J Agromed, 2018; 23(3):227-48.

Lunning M, Vose J, Nastoupil L, Fowler N, Burger JA, Wierda WG, Schreeder MT, Siddiqi T, Flowers CR, Cohen JB, Sportelli P. Ublituximab and umbralisib in relapsed/refractory B-cell non-Hodgkin lymphoma and chronic lymphocytic leukemia. Blood, 2019; 134(21):1811-20.

Marcora SM, Staiano W, Manning V. Mental fatigue impairs physical performance in humans. J Appl Physiol, 2009; 106(3):857-64.

McDonald T, Drescher KM, Weber A, Tracy S. Creatinine inhibits bacterial replication. J Antibiot, 2012; 65(3):153-6.

Mishra SD, Sarkar K. Work-related musculoskeletal disorders and associated risk factors among urban metropolitan hairdressers in India. J Occup Health, 2021; 63(1):e12200. 
Mumoli N, Cei M, Cosimi A. Drug-related hepatotoxicity. N Engl J Med, 2006; 354(20):2191-3.

Oh RC, Hustead TR. Causes and evaluation of mildly elevated liver transaminase levels. Am Fam Physician, 2011; 84(9):1003-8.

Rajabi B, Sweetenham JW. Mantle cell lymphoma: observation to transplantation. Ther Adv Hematol, 2015; 6(1):37-48.

Riordan SM, Williams R. Alcohol exposure and paracetamolinduced hepatotoxicity. Addict Biol, 2002; 7(2):191-206.

Samra M, Abcar AC. False estimates of elevated creatinine. Perm J, 2012; 16(2):51-2.

Sarker D, Ang JE, Baird R, Kristeleit R, Shah K, Moreno V, Clarke PA, Raynaud FI, Levy G, Ware JA, Mazina K. First-in-human phase I study of pictilisib (GDC-0941), a potent pan-class I phosphatidylinositol3-kinase (PI3K) inhibitor, in patients with advanced solid tumors. Clin Cancer Res, 2015; 21(1):77-86.

Scorza K, Williams A, Phillips JD, Shaw J. Evaluation of nausea and vomiting. Am Fam Physician, 2007; 76(1):76-84.

Skarbnik AP, Goy AH. Mantle cell lymphoma: state of the art. Clin Adv Hematol Oncol, 2015; 13(1):44-55.

Sriskandarajah P, Dearden CE. Epidemiology and environmental aspects of marginal zone lymphomas. Best Pract Res Clin Haematol, 2017 30(1-2):84-91.

Sun J, Lin J, Parashette K, Zhang J, Fan R. Association of lymphocytic colitis and lactase deficiency in pediatric population. Pathol Res Pract, 2015; 211(2):138-44.
Takata K, Miyata-Takata T, Sato Y, Iwamuro M, Okada H, Tari A, Yoshino T. Gastrointestinal follicular lymphoma: current knowledge and future challenges. Pathol Int, 2018; 68(1):1-6.

Tytgat GN. Hyoscine butylbromide: a review of its use in the treatment of abdominal cramping and pain. Drugs, 2007; 67(9):1343-57.

Viniol A, Keunecke C, Biroga T, Stadje R, Dornieden K, Bösner S, Donner-Banzhoff N, Haasenritter J, Becker A. Studies of the symptom abdominal pain - a systematic review and meta-analysis. Fam Pract, 2014, 31(5):517-29.

Yang M, Geng L, Chen P, Wang F, Xu Z, Liang C, Li H, Fang T, Friesen CA, Gong S, Li D. Effectiveness of dietary allergen exclusion therapy on eosinophilic colitis in chinese infants and young children $\leq 3$ years of age. Nutrients, 2015; 7(3):1817-27.

\section{How to cite this article:}

Rambabu K, Ramadevi P. Determination of Umbralisib using reverse phase ultra performance liquid chromatography in bulk and pharmaceutical dosage form. J Appl Pharm Sci, 2022; 12(02):172-178. 